\title{
UPAYA MEREDUKSI MISKONSEPSI SISWA PADA MATERI BAHASAN RANGKAIAN LISTRIK SEDERHANA MELALUI MODEL PEMBELAJARAN KOOPERATIF DENGAN STRATEGI KONFLIK KOGNITIF
}

\author{
Mufarridah ${ }^{1,2)}$ \\ Supardi ${ }^{3)}$ \\ Prastowo $^{3)}$ \\ ${ }^{1)}$ Mahasiswa Prodi Pendidikan Sains Pascasarjana Universitas Negeri Surabaya \\ ${ }^{2)}$ Guru Fisika SMA Negeri 2 Bontang \\ ${ }^{3)}$ Dosen Pascasarjana Prodi Pendidikan Sains Universitas Negeri Surabaya \\ e-mail:dian.mufarridah@yahoo.com
}

\begin{abstract}
This study aimed at determining the effect of cooperative teaching learning by using conflict-cognitive strategy towards the reduction of students' misconceptions, so it can be determined a direct correlation between mastery of physics concepts and the misconceptions reduction. To achieve the aim, a study had been conducted beginning by setting the lesson plan, the students' worksheet, and the test in the material of 'simple electrical circuits'. The subject of the study was the students of X in SMAN 15 Surabaya, Second Semester, academic year of 2012-2013. The subject consisted of four groups which were three experimental groups and one control group. The study was an experimental study in control group pretest-posttest research design. The data of the study was collected through a multiple choice test with CRI and argument. The result of the study showed some facts as follows: (1) there was a difference of the mastery significantly of concept between the experiment group and the control group. The average of the mastery of concept of experiment groups was 80,08 while the control group was 62,77; (2) there was the misconception reduction significantly between the experiment group and the control group. The average of the misconception reduction of the experiment group was 32,92\%, while the control group was 11,33\%; and (3) there was correlation between the concept mastery and in regression $Y=0,876-$ 0,095X.The conclusion of the study is that there is a significant effect of the conflict-cognitive strategy to increase the students' learning result and the reduction of students' misconception.
\end{abstract}

\begin{abstract}
Abstrak: Penelitian ini bertujuan menentukan pengaruh model pembelajaran kooperatif dengan strategi konflik kognitif terhadap reduksi miskonsepsi siswa, sehingga dapat ditentukan hubungan langsung antara penguasaan konsep fisika dan reduksi miskonsepsi. Untuk mencapai tujuan tersebut, telah dilakukan penelitian yang diawali dengan penyusunan RPP, LKS dan THB dengan pilihan materi Rangkaian Listrik Sederhana. Subjek penelitian adalah siswa kelas X SMAN 15 Surabaya semester genap Tahun Pembelajaran 2012/2013. Subjek penelitian terdiri atas tiga kelompok eksperimen dan satu kelompok kontrol. Jenis penelitian tergolong penelitian eksperimen dengan menggunakan rancangan penelitian control group pretest-posttest design. Data dikumpulkan melalui THB berbentuk pilihan ganda disertai CRI dan argumentasi. Hasil penelitian menunjukkan: (1) terdapat perbedaan penguasaan konsep secara signifikan antara kelompok eksperimen dan kelompok kontrol. Rata-rata penguasaan konsep siswa kelompok eksperimen adalah 80,08, sedangkan kelompok kontrol 62,77; (2) terdapat perbedaan reduksi miskonsepsi secara signifikan antara kelompok eksperimen dan kelompok kontrol. Rata-rata reduksi miskonsepsi siswa kelompok eksperimen adalah 32,92\%, sedangkan kelompok kontrol 11,33\%; dan (3) terdapat hubungan antara penguasaan konsep dengan reduksi miskonsepsi dalam persamaan regresi $Y=0,876-0,095 \mathrm{X}$. Simpulan penelitian adalah terdapat pengaruh signifikan pembelajaran strategi konflik kognitif terhadap peningkatan hasil belajar dan reduksi miskonsepsi siswa.
\end{abstract}

Kata-kata Kunci: Miskonsepsi, CRI, Pengkodean Argumentasi, Strategi Konflik Kognitif.

\section{PENDAHULUAN}

Fisika dibutuhkan untuk mempelajari fenomena alam yang menuntut kemampuan berpikir dan tindakan nyata secara sistematis, terpadu, dan komprehensif. Dalam hal ini, pembelajaran fisika di sekolah menuntut siswa untuk dapat memahami prinsip dan konsep fisika mulai dari yang sederhana sampai dengan yang kompleks. Pada tataran yang lebih tinggi, siswa juga diharapkan untuk dapat menjelaskan contoh-contoh aplikatif dari prinsip dan konsep fisika yang menjadi topik diskusi dalam kelas.

Kemampuan memahami dan menghubungkan prinsip dan konsep fisika yang diajarkan dengan peristiwa 
alami dalam kehidupan sehari-hari adalah penting, karena kedua hal tersebut bisa mencegah miskonsepsi di kalangan siswa. Seringkali masalah belajar seperti itu muncul dalam kesempatan diskusi kelas yang melibatkan baik antar individu siswa maupun antar kelompok siswa. Perbedaan pandangan merupakan hasil dari perbedaan pemahaman terhadap prinsip dan konsep fisika dan dikenal sebagai konflik kognitif.

Belajar dalam kelas selalu melibatkan interaksi antar siswa. Proses belajar bersifat kooperatif melalui interaksi timbal balik mendorong pertukaran informasi dan pengetahuan antar siswa yang dapat mengubah pembelajaran yang berpusat pada guru (teacher-centered learning) menjadi pembelajaran aktif berpusat pada siswa (student-centered learning). Model pembelajaran kooperatif ini diharapkan juga sebagai suatu alternatif pembelajaran yang melatih siswa untuk mengemukakan pendapat secara lisan dan mengembangkan pola keterampilan berpikir. Hal ini sesuai dengan temuan Sutrisno (2009) yang menyatakan bahwa pembelajaran fisika yang baik dan benar membantu proses pembentukan karakter dan kepribadian siswa melalui pengembangan sikap-sikap positif siswa sebagai berikut: (1) berpikir kritis, logis, dan analitis; (2) bertindak cermat, terbuka, dan jujur; dan (3) berkemampuan komunikasi ilmiah.

Berdasarkan wawancara peneliti dengan guru - guru fisika SMAN 15 Surabaya, terdapat beberapa masalah pembelajaran fisika di SMAN 15 Surabaya yang ditemui baik bagi guru maupun siswa. Masalah bagi guru adalah peran guru belum maksimal dalam: (1) melibatkan siswa sebagai subjek dalam proses belajar mengajar (PBM); (2) menerapkan pola mengajar yang bersifat argumentatif dan objektif; dan (3) memberikan contoh nyata dalam PBM. PBM yang cenderung bersifat teacher-centered menimbulkan masalah bagi siswa, yaitu siswa menjadi kurang: termotivasi, aktif, terampil, dan kritis dalam menganalisis kasus fisika. Salah satu indikator terdapat rentang nilai mata pelajaran fisika yang cukup besar antara nilai tertinggi dan terendah yang dapat dicapai siswa pada Ujian Nasional (UN) pada lima tahun terakhir. Adapun sebaran nilai UN lima tahun terakhir mata pelajaran fisika siswa SMAN 15 Surabaya adalah sebagai berikut. Tahun Pelajaran 2008/2009: nilai terendah 6,25; nilai tertinggi 10,00; dan nilai rata-rata 8,93. Tahun Pelajaran 2009/2010: nilai terendah 6,25; nilai tertinggi 9,00; dan nilai rata-rata 9,10. Tahun Pelajaran 2010/2011: nilai terendah 2,50; nilai tertinggi 8,25 ; dan nilai rata-rata 8,10 . Tahun Pelajaran 2011/2012: nilai terendah 5,25; nilai tertinggi 10,00; dan nilai rata- rata 8,74. Sedangkan Tahun pelajaran 2012/2013: nilai terendah 4,00; nilai tertinggi 10,00; dan nilai rata-rata 8,64 (Sumber: Data kurikulum SMAN 15 Surabaya).

Trumper (1990) mengungkapkan bahwa kesulitan belajar fisika siswa menyebabkan penguasaan konsep siswa rendah. Penguasaan konsep fisika yang rendah menyebabkan rendahnya mutu pendidikan fisika. Dua faktor yang ikut berperan dalam masalah belajar siswa adalah prakonsepsi dan miskonsepsi. Miskonsepsi siswa yang muncul terus menerus akan mengganggu pembentukan konsepsi ilmiah dan mengakibatkan masalah belajar yang dapat mempengaruhi hasil belajar siswa. Dilber et al. (2007) menyatakan bahwa guru harus peduli terhadap prakonsepsi dan miskonsepsi siswa, karena kedua faktor tersebut merupakan faktor penting untuk meningkatkan hasil belajar siswa. Dalam hal ini, miskonsepsi siswa dapat dicegah melalui proses pembelajaran fisika yang baik dan benar.

Miskonsepsi siswa banyak ditemui dalam pembelajaran fisika di sekolah, antara lain pada pokok bahasan mekanika (Sadia, 2004; Saehana dkk, 2009), suhu dan kalor (Baser, 2006; Sirait, 2009; dan Mosik, 2010), fluida (Said, 2012), cahaya (Indrawati, 2009), listrik dinamis (Dilber et al., 2007; Tsai, C-H. et al., 2007; Kucukozer et al., 2007; Simarmata, 2008; Dilber et al., 2008; Faizin, 2009; dan Smith et al., 2011), listrik magnet (Raduka, 2005; Triyana, 2009). Berdasarkan hasil temuan beberapa penelitian di atas, dapat disimpulkan bahwa miskonsepsi dalam pembelajaran fisika terjadi pada hampir semua topik fisika. Pokok bahasan rangkaian listrik sederhana termasuk salah satu topik di mana miskonsepsi banyak terjadi.

Miskonsepsi pada pokok bahasan rangkaian listrik sederhana dialami oleh siswa SMAN 15 Surabaya. Berdasarkan hasil prapenelitian oleh penulis yang dilaksanakan pada 128 siswa kelas X SMAN 15 Surabaya tahun pelajaran 2012/2013, ditemukan adanya miskonsepsi pada pokok bahasan rangkaian listrik sederhana. Persentase miskonsepsi yang dialami siswa terhadap sepuluh konsep yang diujikan adalah lebih besar atau sama dengan $50 \%$.

Miskonsepsi siswa terhadap materi rangkaian listrik sederhana diduga menjadi penyebab rendahnya pencapaian persentase penguasaan siswa SMAN 15 Surabaya terhadap pokok bahasan "menentukan besaranbesaran listrik pada suatu rangkaian berdasarkan hukum Kirchoff" pada UN Tahun Pelajaran 2011/2012 yaitu $79 \%$, lebih rendah dari persentase daya serap untuk: (1) siswa RSBI yaitu $85 \%$; (2) siswa tingkat kabupaten/kota, yaitu $83 \%$, dan (3) siswa tingkat propinsi, yaitu $85 \%$ (Sumber: Dinas Pendidikan Kota Surabaya).

Sehubungan dengan temuan hasil belajar siswa SMAN 15 Surabaya tersebut di atas, perlu dilakukan reorientasi dalam pembelajaran fisika khususnya pada pokok bahasan rangkaian listrik sederhana dengan tujuan untuk mereduksi tingkat miskonsepsi siswa. 
Salah satu strategi belajar yang telah terbukti efektif untuk mereduksi miskonsepsi siswa adalah strategi konflik kognitif. Hal ini sesuai dengan temuan Baser (2006), Sirait (2009), dan Mosik (2010) yang menyatakan bahwa penggunaan strategi konflik kognitif dalam pembelajaran materi suhu dan kalor secara signifikan dapat meningkatkan pemahaman konsep fisika, kemampuan berpikir kritis, dan menurunkan miskonsepsi. Selain itu, Simarmata (2008) menemukan bahwa pendekatan konflik kognitif dalam pembelajaran konstruktivis dapat meningkatkan belajar mandiri siswa dan lebih efektif meluruskan kesalahan konsep siswa pada pokok bahasan listrik searah.

Berdasarkan kebermanfaatan strategi konflik kognitif dalam pembelajaran fisika, maka peneliti menerapkan strategi konflik kognitif dengan mengadopsi model pembelajaran kooperatif sebagai model pembelajaran yang dijadikan basis utama untuk melaksanakan penelitian. Penerapan model pembelajaran kooperatif dengan strategi konflik kognitif pada pokok bahasan rangkaian listrik sederhana diharapkan dapat mereduksi miskonsepsi siswa.

Pembelajaran fisika yang efektif dapat dilakukan dengan memperkenalkan multimedia sebagai salah satu sarana alternatif pendukung PBM, antara lain penggunaan media komputer dan KIT sederhana. Kebermanfaatan pembelajaran berbasis komputer dapat dilihat dari hasil temuan Mardana (2004), Saehana, dkk (2006), dan Faizin (2009) yang menyatakan bahwa model pembelajaran berbantuan simulasi komputer secara signifikan dapat menurunkan miskonsepsi, meningkatkan hasil belajar fisika, meningkatkan penguasaan konsep listrik dinamis, dan juga dapat memperbaiki sikap belajar. Sedangkan Samsuri (2010) lebih jauh mengungkapkan bahwa pembelajaran fisika pokok bahasan listrik dinamis dapat berjalan lebih efektif dengan menggunakan simulasi PhET dan KIT sederhana.

Berdasarkan hasil-hasil temuan penelitian tersebut di atas, maka peneliti melakukan penelitian pendidikan yang memanfaatkan media simulasi komputer Physics Education Technology (PhET) dan KIT untuk mempelajari pokok bahasan rangkaian listrik sederhana. Pemilihan pokok bahasan rangkaian listrik sederhana dalam penelitian ini dengan pertimbangan bahwa konsep fisika pada pokok bahasan rangkaian listrik sederhana bersifat abstrak, sehingga memerlukan media yang dapat menjembatani konsep fisika pada pokok bahasan rangkaian listrik sederhana dan kemampuan pemahaman konsep siswa agar tidak terjadi miskonsepsi. Kombinasi pembelajaran dengan media simulasi PhET dan KIT sederhana diharapkan dapat menambah wawasan siswa, meningkatkan hasil belajar dalam konteks penerapan model pembelajaran kooperatif dengan strategi konflik kognitif, dan mereduksi miskonsepsi siswa.

Studi ini memberikan gambaran implementasi model pembelajaran kooperatif dengan strategi konflik kognitif dalam meningkatkan penguasaan konsep dan mereduksi miskonsepsi siswa terhadap materi Rangkaian Listrik Sederhana. Secara spesifik penelitian ini menjawab pertanyaan-pertanyaan penelitian sebagai berikut: (1) Bagaimana perbedaan penguasaan konsep fisika siswa setelah pembelajaran?; (2) Bagaimana perbedaan reduksi miskonsepsi siswa setelah pembelajaran?; dan (3) Bagaimana hubungan antara penguasaan konsep fisika dan reduksi miskonsepsi siswa?

\section{METODE PENELITIAN}

Penelitian ini merupakan penelitian eksperimen dengan rancangan penelitian Control Group PretesPosttes satu perlakuan. Penelitian dilakukan di SMAN 15 Surabaya tahun pelajaran 2012/2013. Populasi dalam penelitian ini adalah siswa kelas X SMAN 15 Surabaya yang berjumlah sebelas kelas yaitu X1 sampai X11, dan diambil sampel sebanyak 4 kelas (3 kelas eksperimen dan 1 kelas kontrol) dengan teknik sampel cluster.

Penelitian ini dilakukan melalui dua tahapan, yaitu tahap persiapan yang merupakan tahap rancangan pengembangan perangkat pembelajaran hasil modifikasi dari model pengembangan perangkat pembelajaran 4-D yang direduksi menjadi model pembelajaran 3-D dan tahap pelaksanaan penelitian uji coba perangkat pembelajaran di kelas.

Instrumen yang digunakan untuk mengumpulkan data dalam penelitian ini dapat dikelompokkan menjadi instrumen utama dan instrumen pendukung. Instrumen utama terdiri dari tes penguasaan konsep dan wawancara. Instrumen pendukung terdiri dari lembar keterlaksanaan pembelajaran, angket respons siswa, dan lembar pengamatan aktivitas siswa.

Teknik analisis data yang digunakan meliputi: (1) CRI (Certainty of Response Index) digunakan untuk mendeteksi miskonsepsi pada soal pilihan ganda, dan pengkodean argumentasi digunakan untuk mendeteksi miskonsepsi pada argumentasi yang diberikan siswa; (2) uji-t dilanjutkan dengan analisis n-gain, analisis persentase, dan analisis regresi untuk menguji hipotesis.

Pengidentifikasian miskonsepsi menggunakan CRI dilakukan secara individu dan kelompok. Pengidentifikasian secara individu dimaksudkan untuk mengetahui persentase siswa yang mengalami miskonsepsi pada sejumlah konsep yang diberikan. Bentuk matriks jawaban siswa secara individu dapat dilihat pada Tabel 1.

Tabel 1. Penentuan Tingkat Pemahaman Konsep 


\begin{tabular}{|c|c|c|}
\hline $\begin{array}{c}\text { Tipe } \\
\text { Jawaban }\end{array}$ & CRI Rendah $(<2,5)$ & $\begin{array}{c}\text { CRI Tinggi ( }> \\
2,5)\end{array}$ \\
\hline $\begin{array}{c}\text { Jawaban } \\
\text { benar }\end{array}$ & $\begin{array}{l}\text { Jawaban benar dan } \\
\text { CRI rendah, berarti } \\
\text { siswa menjawab } \\
\text { benar karena } \\
\text { keberuntungan (lucky } \\
\text { guess) }\end{array}$ & $\begin{array}{l}\text { Jawaban benar } \\
\text { dan CRI tinggi, } \\
\text { berarti siswa } \\
\text { menguasai } \\
\text { konsep dengan } \\
\text { baik }\end{array}$ \\
\hline $\begin{array}{c}\text { Jawaban } \\
\text { salah }\end{array}$ & $\begin{array}{l}\text { Jawaban salah dan } \\
\text { CRI rendah, berarti } \\
\text { siswa tidak tahu } \\
\text { konsep (lack of } \\
\text { knowledge) }\end{array}$ & $\begin{array}{l}\text { Jawaban salah } \\
\text { dan CRI tinggi, } \\
\text { berarti siswa } \\
\text { mengalami } \\
\text { miskonsepsi }\end{array}$ \\
\hline
\end{tabular}

Pengidentifikasian miskonsepsi menggunakan CRI secara kelompok dimaksudkan untuk mengetahui konsep apa yang memiliki level miskonsepsi paling tinggi di antara konsep lainnya. Identifikasi secara kelompok ditentukan dari nilai CRIB (rata-rata CRI siswa yang menjawab benar), CRIS (rata-rata siswa yang menjawab salah), dan $\mathrm{Fb}$ (fraksi siswa yang menjawab benar).

Miskonsepsi terjadi jika nilai CRIS $(2,5<$ CRIS $\leq$ 5). Jika CRIS mendekati 2,5, maka untuk menentukan siswa mengalami miskonsepsi atau tidak dilihat dari nilai $\mathrm{Fb}$. Jika $\mathrm{Fb}>0,5$ berarti CRIS tergolong rendah, sehingga siswa dianggap tidak tahu konsep. Jika $\mathrm{Fb}<0,5$ berarti CRIS tergolong tinggi, sehingga siswa dianggap miskonsepsi. Semakin tinggi nilai CRIS, maka tingkat miskonsepsi juga semakin tinggi karena keyakinan yang ditunjukkan siswa juga tinggi meskipun memilih jawaban yang salah.

Panduan untuk menganalisis argumentasi yang diberikan siswa pada tes pemahaman konsep sebagai panduan mengidentifikasi adanya miskonsepsi disajikan sebagai berikut:

a. Secara ilmiah benar (A): penjelasan benar secara ilmiah.

b. Mendekati benar (B) : penjelasan yang diberikan benar tetapi dalam penjelasan lengkap dianggap berada di tingkat ini.

c. Tidak benar 1 (C) : secara ide benar namun kalimat yang dipergunakan untuk menjelaskan salah.

d. Tidak benar 2 (D) : penjelasan terfokus pada bagian kecil dan bagian besar dari suatu konsep, namun cara menghubungkannya sesuai dengan level ini.

e. Tidak benar 3 (E) : ide mengenai konsep dan penjelasan yang diberikan tidak dapat dibenarkan secara ilmiah.

f. Tidak terkodekan $(\mathrm{F})$ : penjelasan yang diberikan tidak berhubungan dengan soal yang diajukan.

g. Tidak ada penjelasan (G) : siswa tidak memberikan argumentasi (Kucukozer et al., 2007).
Tingkatan yang digunakan untuk penckodean argumentasidapat dilihat pada Gambar 1 .

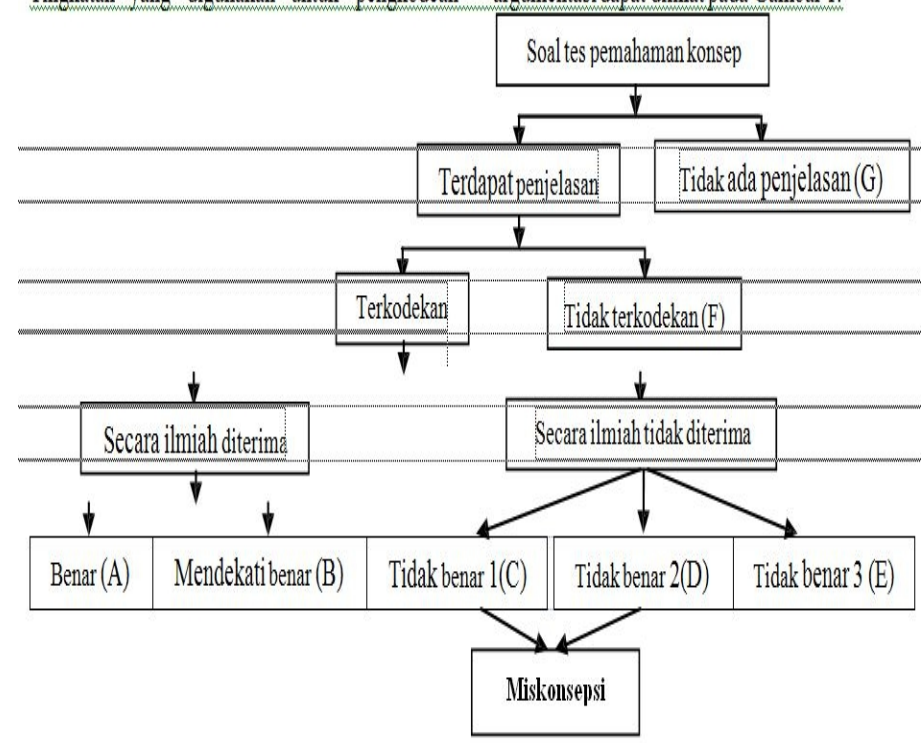

Gambar 1. Analisis Terhadap Tes Pemahaman Konsep (Kucukozer et al., 2007).

\section{HASIL DAN PEMBAHASAN}

Hasil pengamatan pengamat independen terhadap keterlaksanaan pembelajaran menunjukkan bahwa guru secara konsisten dapat melaksanaan langkah-langkah pembelajaran sebagaimana tertera dalam perangkat pembelajaran yang telah dikembangkan, antusiasme siswa untuk terlibat dalam kegiatan pembelajaran dengan strategi konflik kognitif adalah baik. Dengan demikian, dapat dikatakan bahwa guru dan siswa dapat beradaptasi dengan baik terhadap perangkat pembelajaran kooperatif dengan strategi konflik kognitif.

Kepekaan butir soal terhadap efek-efek pembelajaran diukur dengan uji sensitivitas butir soal. Indeks sensitivitas masing-masing item soal sebagai berikut:1 $(0,6), 2(0,31), 3(0,4), 4(0,5), 5(0,3), 6(0,6), 7$ $(0,4), 8(0,3), 9(0,4)$, dan $10(0,4)$. Dari 10 butir soal yang diujikan, semua butir soal memiliki kriteria peka terhadap efek-efek pembelajaran.

Melalui analisis aspek kompleksitas, daya dukung, dan intake siswa pada tiap indikator butir tes, didapatkan Kriteria Ketuntasan Minimal (KKM) indikator untuk tiap butir soal pada tes penguasaan konsep (pretest dan posttest) yaitu: (1) 66,7 ; (2) 66,7 ; (3) 66,7 ; (4) 77,8 ; (5) 55,5 ; (6) 66,7; (7) 77,8; (8) 77,8; (9) 66,7; dan (10) 77,8. Adapun ketercapaian KKM indikator disajikan pada Tabel 2 di bawah ini.

Tabel 2. Ketercapaian KKM Indikator pada Posttest
\begin{tabular}{|l|l|l|l|l|l|l|l|l|l|l|l|}
\hline $\begin{array}{l}\text { N } \\
\mathbf{0}\end{array}$ & Kelas & $\mathbf{1}$ & $\mathbf{2}$ & $\mathbf{3}$ & $\mathbf{4}$ & $\mathbf{5}$ & $\mathbf{6}$ & $\mathbf{7}$ & $\mathbf{8}$ & $\mathbf{9}$ & $\mathbf{1}$ \\
\hline 1 & Eksper & 6 & 8 & 9 & 7 & 4 & 6 & 6 & 8 & 9 & 7 \\
& imen & 0 & 4 & 2 & 7 & 0 & 2 & 9 & 2 & 2 & 1 \\
\hline 2 & Kontro & 5 & 6 & 7 & 3 & 3 & 6 & 3 & 5 & 3 & 1 \\
& 1 & 0 & 5 & 2 & 1 & 1 & 3 & 8 & 9 & 8 & 9 \\
\hline
\end{tabular}


Berdasarkan KKM indikator, diperoleh rerata yang merupakan KKM kompetensi dasar (KD) untuk materi bahasan rangkaian listrik sederhana adalah 70. KKM KD ini lebih rendah dari KKM yang disarankan KTSP yaitu 75\%. Hal ini dikarenakan indikator yang dikembangkan dalam perangkat pembelajaran dengan strategi konflik kognitif lebih tinggi dari indikator yang dikehendaki pada KTSP mata pelajaran fisika untuk KD rangkaian listrik sederhana. Persentase ketuntasan KKM klasikal ditunjukkan secara grafis seperti terlihat pada Gambar 1.

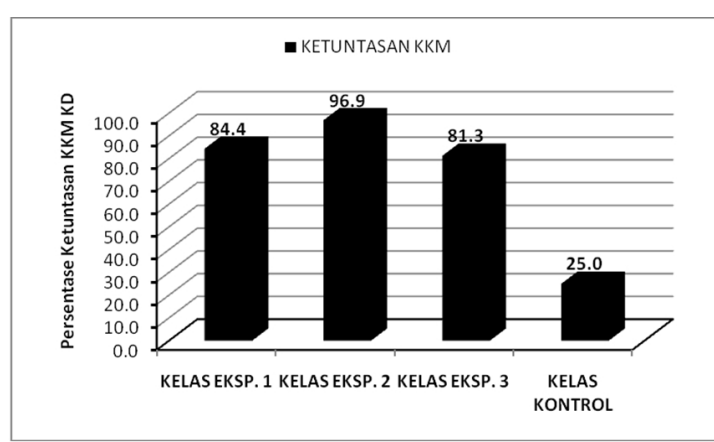

Gambar 2. Profil Ketuntasan KKM

Rerata penguasaan konsep siswa sebelum (pretest) dan sesudah pembelajaran (posttest), serta perubahan rerata penguasaan konsep disajikan pada Tabel 3.

Tabel 3. Perubahan Rata-rata Penguasaan Konsep

\begin{tabular}{|c|l|c|c|c|}
\hline No & \multicolumn{1}{|c|}{ Kelas } & Pretest & Posttest & Perubahan \\
\hline 1 & $\begin{array}{l}\text { Eksperimen } \\
1\end{array}$ & 36,95 & 77,80 & 40,85 \\
\hline 2 & $\begin{array}{l}\text { Eksperimen } \\
2\end{array}$ & 39,75 & 85,80 & 46,05 \\
\hline 3 & $\begin{array}{l}\text { Eksperimen } \\
3\end{array}$ & 33,84 & 76,63 & 42,79 \\
\hline 4 & Kontrol & 38,76 & 62,77 & 25.45 \\
\hline
\end{tabular}

Berdasarkan Tabel 3, didapatkan bahwa rerata penguasaan konsep kelas eksperimen lebih baik daripada kelas control dengan persentase: 19,3\% (kelas eksperimen 1); 26,8 \% (kelas eksperimen 2); dan 18,2\% kelas eksperimen 3).

Selanjutnya, untuk mengetahui apakah peningkatan penguasaan konsep yang terjadi pada siswa, diakibatkan oleh pembelajaran yang telah dilaksanakan, maka dilakukan analisis deskriptif n-gain (Hake, 1999). Hasil analisis n-gain disajikan pada Gambar 3.

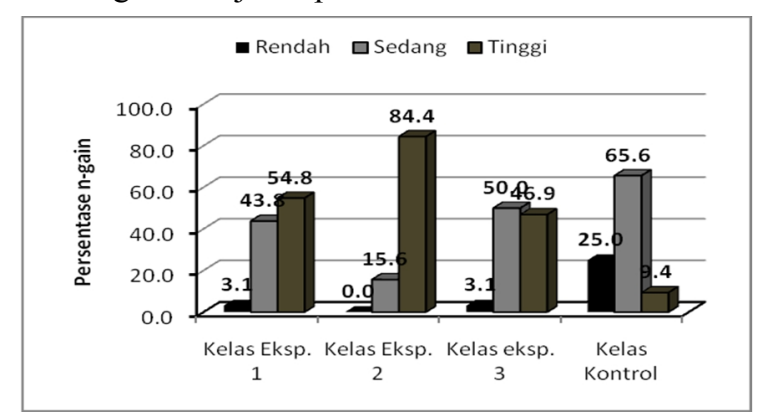

Gambar 3. Ringkasan Hasil Analisis n-gain
Berdasarkan hasil analisis tersebut dapat dilihat bahwa persentase n-gain terbesar kelas eksperimen di kategori tinggi, sedangkan pada kelas kontrol persentase terkecil di kategori tinggi, sehingga dapat disimpulkan bahwa pembelajaran kooperatif dengan strategi konflik kognitif lebih berpengaruh atau lebih efektif dalam meningkatkan penguasaan konsep siswa dibandingkan pembelajaran sejenis tanpa strategi konflik kognitif.

Hasil identifikasi miskonsepsi secara individu dengan menggunakan CRI pada data pretest dan posttest siswa kelas eksperimen dan kelas kontrol, serta reduksi miskonsepsi yang terjadi disajikan pada Tabel 4.

Tabel 4. Reduksi Miskonsepsi Per Konsep Hasil Analisis CRI

\begin{tabular}{|c|c|c|c|c|c|c|}
\hline \multirow{3}{*}{$\begin{array}{c}\text { Nom } \\
\text { or } \\
\text { Kons } \\
\text { ep }\end{array}$} & \multirow{2}{*}{\multicolumn{2}{|c|}{$\begin{array}{c}\text { Kelas } \\
\text { Eksperimen } \\
\begin{array}{c}\text { Miskonsepsi } \\
(\%)\end{array} \\
\end{array}$}} & \multirow{3}{*}{$\begin{array}{c}\text { Redu } \\
\text { ksi } \\
(\%)\end{array}$} & \multirow{2}{*}{\multicolumn{2}{|c|}{$\begin{array}{c}\text { Kelas } \\
\text { Kontrol } \\
\begin{array}{c}\text { Miskonsepsi } \\
(\%)\end{array} \\
\end{array}$}} & \multirow{3}{*}{$\begin{array}{c}\text { Redu } \\
\text { ksi } \\
(\%)\end{array}$} \\
\hline & & & & & & \\
\hline & $\begin{array}{c}\text { Prete } \\
\text { st }\end{array}$ & $\begin{array}{c}\text { Poste } \\
\text { st }\end{array}$ & & $\begin{array}{c}\text { Prete } \\
\text { st }\end{array}$ & $\begin{array}{c}\text { Poste } \\
\text { st }\end{array}$ & \\
\hline 1 & 79,6 & 30,2 & 49,4 & 56,3 & 46,9 & 9,4 \\
\hline 2 & 33,3 & 5,2 & 28,1 & 37,5 & 3,1 & 34,4 \\
\hline 3 & 26,0 & 5,2 & 20,8 & 18,8 & 6,3 & 12,5 \\
\hline 4 & 30,2 & 2,1 & 28,1 & 25,0 & 0,0 & 25,0 \\
\hline 5 & 53,1 & 47,9 & 5,2 & 40,6 & 12,5 & 27,9 \\
\hline 6 & 72,9 & 31,3 & 41,6 & 28,1 & 12,5 & 15,6 \\
\hline 7 & 38,5 & 21,9 & 16,6 & 18,8 & 12,5 & 6,3 \\
\hline 8 & 32,3 & 9,4 & 22,9 & 25,0 & 21,9 & 3,1 \\
\hline 9 & 34,4 & 7,3 & 27,1 & 56,2 & 43,8 & 13,4 \\
\hline 10 & 30,3 & 13,5 & 16,8 & 31,3 & 37,5 & $-6,2$ \\
\hline
\end{tabular}

Berdasarkan Tabel 4, dapat dilihat bahwa: (1) Persentase reduksi miskonsepsi pada kelas eksperimen hasil analisis CRI untuk 9 konsep dari 10 konsep yang diujikan besarnya di atas 15,0\%. Sedangkan untuk konsep nomor (5) beda potensial di antara dua titik, persentase reduksi miskonsepsi adalah sebesar 5,2\%; (2) Persentase reduksi miskonsepsi pada kelas kontrol hasil analisis CRI terjadi pada 9 konsep dari 10 konsep yang diujikan dengan besar di atas 3\%. Sedangkan pada konsep (10) pengaruh pemasangan amperemeter dan voltmeter dalam rangkaian, persentase miskonsepsi siswa mengalami kenaikan sebesar 6,2\%. Reduksi miskonsepsi siswa kelas eksperimen lebih tinggi daripada kelas kontrol dengan persentase: 49,21\% (kelas kepserimen 1), $77,33 \%$ (kelas eksperimen 2), dan 62,35\% (kelas eksperimen 3).

Hasil identifikasi CRI terhadap data pretest secara kelompok disajikan pada Gambar 4 dan Gambar 5. 


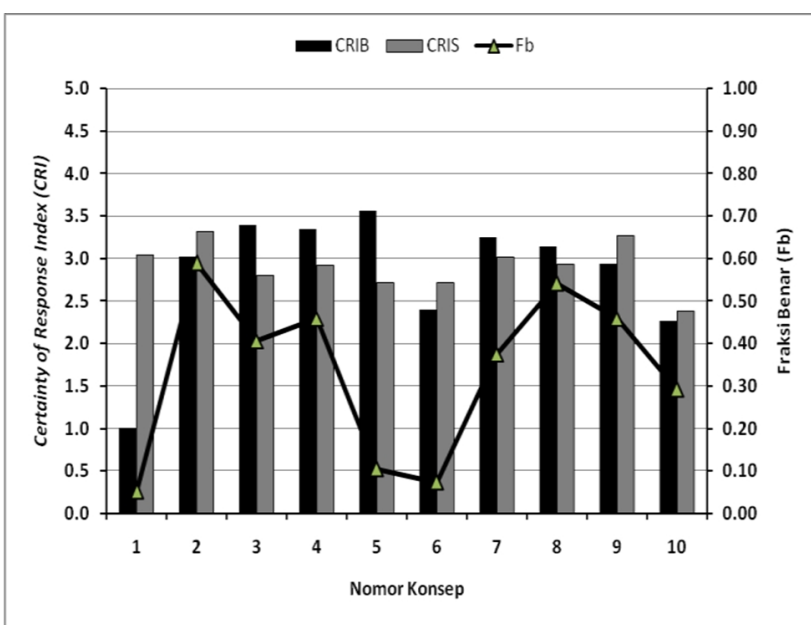

Gambar 4. Grafik CRIB, CRIS, dan Fb Pretest Kelas

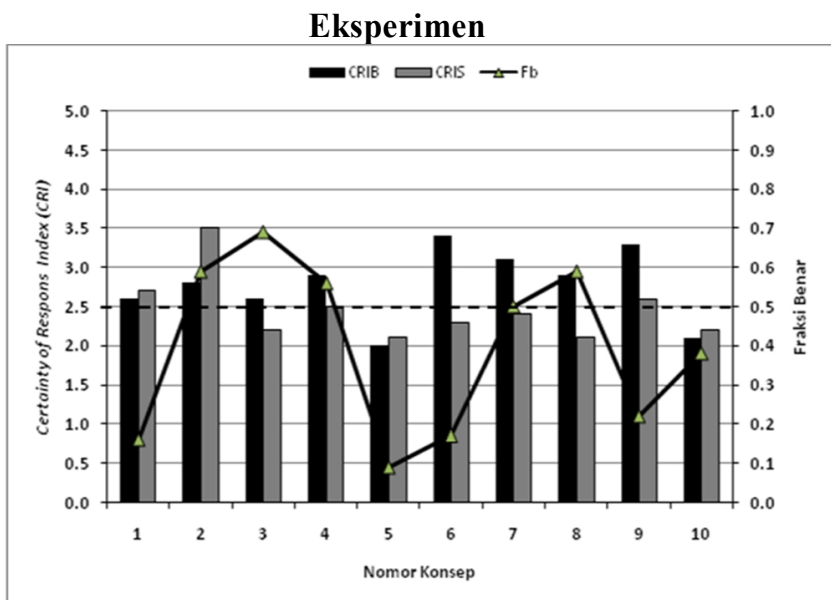

Gambar 5. Grafik CRIB, CRIS, dan Fb Pretest Kelas Kontrol

Berdasarkan hasil analisis terhadap data pretest siswa pada kelas eksperimen dapat dilihat bahwa pemahaman sejumlah siswa berada pada ketegori miskonsepsi terhadap konsep-konsep dengan nomor (1), (3), (4), (5), (6), (7), dan (9). Sedangkan untuk kelas kontrol, siswa mengalami miskonsepsi pada konsepkonsep nomor (1) dan (9). Dampak miskonsepsi terkuat yang dialami siswa baik kelas eksperimen maupun kelas kontrol diakibatkan oleh konsep nomor (1), di mana persentase siswa yang menjawab benar pada kelas eksperimen dan kelas kontrol kurang dari $20 \%$.

Hasil identifikasi CRI terhadap data posttest secara kelompok disajikan pada Gambar 6 dan Gambar 7.

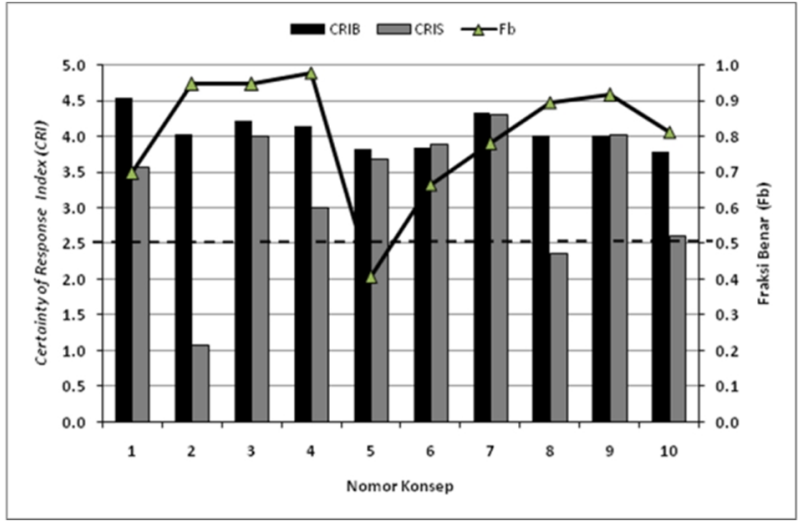

Gambar 6. Grafik CRIB, CRIS, dan Fb Posttest Kelas Eksperimen

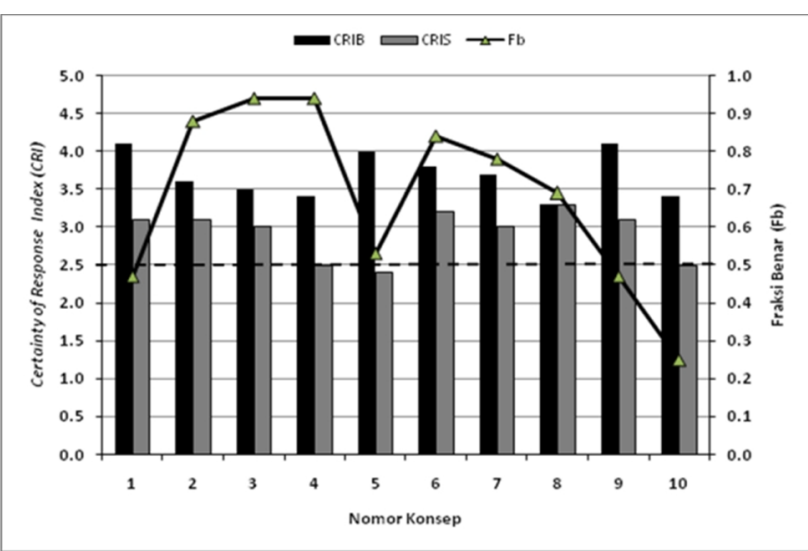

Gambar 7. Grafik CRIB, CRIS, dan Fb Posttest Kelas Kontrol

Berdasarkan hasil analisis terhadap data posttest pada kelas eksperimen, siswa mengalami miskonsepsi pada konsep (5). Miskonsepsi siswa terhadap konsep nomor (5) bersifat resistan. Sedangkan pada kelas kontrol, siswa mengalami miskonsepsi pada konsep (1), (9), dan (10). Miskonsepsi siswa bersifat resisten terhadap konsep nomor (1) dan (9). Berdasarkan hasil analisis CRI secara kelompok terhadap konsep-konsep tersebut baik pada kelas eksperimen maupun kelas kontrol, didapatkan bahwa $\mathrm{Fb}>0,2$. Hal ini berarti bahwa jumlah siswa yang menjawab benar terhadap konsep nomor (5) untuk kelas eksperimen dan konsep nomor (1) dan (9) untuk kelas kontrol di atas $20 \%$. Sehingga dapat dikatakan bahwa dampak miskonsepsi yang diakibatkan konsep-konsep tersebut cenderung tidak kuat.

Identifikasi miskonsepsi yang dialami siswa dapat ditelusuri dari argumentasi yang diberikan untuk memperkuat jawaban pada tiap butir soal. Hasil identifikasi miskonsepsi dengan menggunakan pengkodean argumentasi kelas eksperimen dan kelas kontrol, serta reduksi miskonsepsi disajikan pada Tabel 5. 
Tabel 5. Reduksi Miskonsepsi Hasil Analisis Pengkodean Argumentasi

\begin{tabular}{|c|c|c|c|c|c|c|}
\hline \multirow{3}{*}{$\begin{array}{c}\text { Nom } \\
\text { or } \\
\text { Kons } \\
\text { ep }\end{array}$} & \multirow{2}{*}{\multicolumn{2}{|c|}{$\begin{array}{c}\text { Kelas } \\
\text { Eksperimen } \\
\begin{array}{c}\text { Miskonsepsi } \\
(\%)\end{array} \\
\end{array}$}} & \multirow{3}{*}{$\begin{array}{c}\text { Redu } \\
\text { ksi } \\
(\%)\end{array}$} & \multirow{2}{*}{\multicolumn{2}{|c|}{$\begin{array}{c}\text { Kelas } \\
\text { Kontrol } \\
\text { Miskonsepsi } \\
(\%)\end{array}$}} & \multirow{3}{*}{$\begin{array}{c}\text { Redu } \\
\text { ksi } \\
\text { (\%) }\end{array}$} \\
\hline & & & & & & \\
\hline & $\begin{array}{c}\text { Prete } \\
\text { st }\end{array}$ & $\begin{array}{c}\text { Poste } \\
\text { st }\end{array}$ & & $\begin{array}{c}\text { Prete } \\
\text { st }\end{array}$ & $\begin{array}{c}\text { Poste } \\
\text { st }\end{array}$ & \\
\hline 1 & 68,8 & 35,4 & 33,4 & 59,4 & 34,4 & 25,0 \\
\hline 2 & 50,0 & 12,5 & 37, & 37,5 & 28,1 & 9,4 \\
\hline 3 & 62,5 & 6,2 & 56,2 & 50,0 & 12,5 & 37,5 \\
\hline 4 & 49,9 & 8,3 & 37, & 62,5 & 21,9 & 40,6 \\
\hline 5 & 67,6 & 49,9 & 17,7 & 59,4 & 37,5 & 21,9 \\
\hline 6 & 78,1 & 34,4 & 43,7 & 46,9 & 21,9 & 25,0 \\
\hline 7 & 57,2 & 19,8 & 37,4 & 68,8 & 40,7 & 28,1 \\
\hline 8 & 51,1 & 15,6 & 35,5 & 28,2 & 31,3 & $-3,1$ \\
\hline 9 & 42,7 & 7,3 & 35,4 & 62,8 & 50,1 & 12,7 \\
\hline 10 & 55,2 & 23,9 & 31,3 & 50,0 & 62,5 & $-12,5$ \\
\hline
\end{tabular}

Berdasarkan Tabel 5, dapat dilihat bahwa: (1) Sejumlah siswa pada kelas eksperimen masih mengalami miskonsepsi argumentasi terhadap 10 konsep yang diujikan. Persentase reduksi miskonsepsi argumentasi siswa pada tiap konsep di atas $15,0 \%$; (2) Miskonsepsi argumentasi yang dialami siswa kelas kontrol tereduksi sebanyak 8 konsep dengan reduksi lebih besar sama dengan 9,4\%. Persentase miskonsepsi pada konsep (8) dan (10) mengalami kenaikan. Reduksi miskonsepsi siswa kelas eksperimen lebih tinggi daripada kelas kontrol dengan persentase: 59,17\% (kelas kepserimen 1), $66,90 \%$ (kelas eksperimen 2), dan 48,97 \% (kelas eksperimen 3).

Argumentasi siswa berlabel miskonsepsi terhadap konsep (1) antara lain: (a) lampu dapat menyala karena kabel dihubungkan di kedua kutub lampu; (b) jika lampu langsung menempel pada baterei, maka lampu akan menyala hanya jika ditempelkan pada kutub positif baterei; (c) beda potensial mengalir dalam rangkaian. Argumentasiargumentasi tersebut mungkin disebabkan oleh pengalaman siswa yang kurang. Berdasarkan hasil wawancara terhadap perwakilan siswa dari masing- masing kelompok, didapatkan bahwa faktor yang diduga sebagai sumber miskonsepsi yang dialami siswa pada konsep ini adalah guru, buku, teman, dan lingkungan. Dengan demikian dapat dikatakan bahwa siswa masih membawa pengalaman dari pengalaman belajar di tingkat sebelumnya. Sumber belajar yang memberikan pengalaman belajar yang tidak sesuai dengan konsepsi ilmiah, dapat memicu terjadinya miskonsepsi pada siswa (Ibrahim, 2012).

Miskonsepsi pada konsep yang sama juga dialami oleh mahasiswa jurusan fisika semester genap pada salah satu perguruan tinggi swasta di kota Palu dengan persentase 52,18\% (Mansyur dkk, 2009). Argumentasi yang digunakan mahasiswa untuk memperkuat jawaban yang diberikan adalah karena lampu memiliki kutub. Temuan tersebut membuktikan bahwa miskonsepsi dapat terjadi pada tingkat pendidikan yang lebih rendah sampai tingkat pendidikan tinggi, jika tidak diluruskan maka akan mengganggu pemahaman materi pelajaran berikutnya dan mengakibatkan hasil belajar yang rendah.

Argumentasi siswa berlabel miskonsepsi terhadap konsep (2) antara lain: (a) lampu yang dipasang pada dua buah baterei yang terangkai paralel akan menyala lebih terang dibandingkan lampu yang dipasang pada sebuah baterai; (b) nyala lampu yang dipasang pada dua baterei tersusun seri akan sama terang dengan nyala lampu yang dipasang pada dua baterei tersusun paralel; dan (c) baterai tidak bisa dirangkai secara paralel, karena berapapun baterai yang disusun paralel, maka yang dapat bekerja hanya satu baterai. Jika argumentasi tersebut dianalisis, maka tampak bahwa siswa fokus pada bagian kecil tertentu yaitu jumlah baterei. Terlihat bahwa logika atau penalaran yang digunakan siswa dalam menarik kesimpulan atau menggeneralisasi salah. Dengan pemikiran yang tidak lengkap seperti ini dapat mengakibatkan terjadinya miskonsepsi (Ibrahim, 2012:14).

Argumentasi yang berlabel miskonsepsi terhadap konsep (3) antara lain: (a) kuat arus listrik pada titik yang lebih dekat dengan baterei lebih besar daripada di titik yang jauh dari baterei; (b) arus melewati titik 1 lebih dahulu dan energi dari baterai belum terserap oleh lampu sehingga kuat arus listrik pada titik 1 lebih besar daripada titik 2; dan (c) lampu mengkonsumsi arus listrik, sehingga kuat arus listrik pada titik 2 lebih kecil daripada di titik 1.

Argumentasi yang berlabel miskonsepsi seperti pada (b) juga dialami oleh siswa Taiwan. Hasil penelitian Tsai C-H et al.(2007) menjelaskan bahwa hanya 19\% dari 7.145 siswa pada eighth and ninth graders dan $28 \%$ dari 2.857 siswa pada 11th grader's yang dapat membedakan konsep arus listrik dan energi listrik, selebihnya mengalami miskonsepsi. Miskonsepsi argumentasi (a) dan (c) tergolong miskonsepsi argumentasi yang umum ditemui terjadi pada siswa. Miskonsepsi seperti ini juga dialami oleh siswa Turki pada sekolah menengah (Secondary school). Hasil penelitian Kucukozer et al. (2007), menunjukkan bahwa siswa pada tingkat sekolah menengah di Turki mengalami miskonsepsi "arus listrik berkurang setelah melewati lampu" dengan persentase sebesar 34,2\%, dengan kata lain argumentasi siswa menjelaskan bahwa "komponen listrik mengkonsumsi arus listrik". Sedangkan Tsai C-H et al.(2007) menemukan bahwa siswa Taiwan pada eighth and ninth graders mengalami miskonsepsi ini dengan persentase sebesar $22 \%$ dan pada $11^{\text {th }}$ grader's sebesar $16 \%$. Ketidakmampuan siswa dalam menguasai konsep kekekalan muatan sebagai konsep prasyarat dari konsep arus listrik dalam rangkaian sederhana 
mengantarkan siswa pada miskonsepsi (Ibrahim, 2012: 14).

Argumentasi yang berlabel miskonsepsi terhadap konsep (4) antara lain: (a) semakin banyak jumlah lampu, lampu yang berada paling jauh dari baterei semakin redup karena semakin besar hambatan yang dilalui; (b) lampulampu yang disusun seri memiliki tegangan yang sama; (c) pada rangkaian seri, tegangan dan kuat arus terbagi rata ke semua lampu; (d) lampu terjauh tidak memiliki hambatan atau nol; dan (e) arus listrik dalam rangkaian seri akan memiliki besar yang tetap walaupun jumlah lampu bertambah. Miskonseps argumentasi dikarenakan siswa tidak memahami karakteristik rangkaian seri secara utuh. Dengan kata lain siswa tidak mampu membedakan karakteristik penentu yaitu kuat arus listrik dari sejumlah karakteristik umum yang dimiliki oleh konsep pada rangkaian seri. Reasioning yang tidak lengkap merupakan salah satu penyebab terjadinya miskonsepsi pada siswa (Ibrahim, 2012: 14).

Argumentasi (a) yang diberikan siswa menunjukkan bahwa siswa berpandangan pada rangkaian seri, lampu mengkonsumsi arus listrik. Senada dengan miskonsepsi argumentasi (b) dan (c) yang dialami oleh siswa SMAN 15 Surabaya, Tsai C-H et al.(2007) dalam penelitian pada rangkaian seri dua lampu menuliskan bahwa siswa Taiwan untuk 11th grader's mengalami miskonsepsi sebesar 14\% dengan argumentasi bahwa tegangan pada dua lampu yang tersusun seri adalah sama besar.

Argumentasi berlabel miskonsepsi pada konsep (5) antara lain: (a) arus masuk sama dengan arus keluar, berarti beda potensialnya sama saja selama rangkaian di dalam rangkaian seri; (b) pada rangkaian seri dengan jumlah baterai dan hambatan satu, maka tegangan di tiap titik besarnya sama; (c) tegangan mengalir dalam rangkaian sehingga semakin ke kutub tegangan semakin kecil; dan (d) tegangan berkurang karena listriknya telah menjadi energi cahaya dan kalor untuk lampu. Argumentasi-argumentasi siswa tersebut merupakan "anggapan pribadi" terhadap konsep beda potensial di antara dua titik karena siswa salah dalam menginterpretasi hukum Ohm. Menurut Ibrahim (2012:16) bahwa "anggapan pribadi" atau intuisi yang salah sering membuat siswa tidak kritis dan mengakibatkan miskonsepsi dikalangan siswa.

Argumentasi (d) mengindikasikan bahwa siswa tidak dapat membedakan konsep arus dan energi, sehingga menggunakannya secara bergantian. Tsai C-H et al.(2007) menemukan bahwa miskonsepsi seperti ini juga dialami oleh siswa Taiwan 19\% siswa tingkat eighth dan 28\% tingkat ninth, mereka kesulitan dalam membedakan arus listrik dan energi listrik.

Argumentasi berlabel miskonsepsi yang digunakan siswa untuk mendukung jawaban terhadap konsep (6) yang dipilih antara lain: (a) urutan tingkat terang nyala lampu: lampu tunggal dirangkai seri dengan sebuah baterei $>$ dua lampu dirangkai seri dengan sebuah baterai $>$ dua lampu dirangkai paralel dengan sebuah baterei; (b) terang nyala dua lampu dirangkai seri sama dengan terang nyala dua lampu dirangkai paralel; dan (c) lampu-lampu yang dirangkai seri lebih terang daripada dirangkai paralel. Siswa memberikan argumentasi seperti yang telah dijabarkan karena pengetahuan konsep siswa belum lengkap dan sederhana, siswa tidak memahami prasyarat yang diperlukan untuk menentukan tingkat terang nyala lampu. Pengetahuan konsep siswa yang belum lengkap dan sederhana (karena tahap perkembangan yang belum mencapai tingkat berpikir abstrak) dapat memicu terjadinya miskonsepsi (Ibrahim, 2012: 14).

Miskonsepsi (a) dan (b) juga ditemukan pada penelitian Kucukozer et al.(2007). Kucukozer et al. (2007) menemukan bahwa siswa mengalami miskonsepsi terhadap konsep terang nyala lampu pada rangkaian seri dan paralel. Siswamemberikan argumentasi "baterai merupakan sumber arus konstan" dengan persentase sebesar 36,8\%, "terdapat pengaruh jumlah lampu terhadap tingkat terang nyala lampu" sebesar 31,5\% dan "terdapat hubungan lurus antara jumlah lampu dengan tingkat terang nyala lampu (tidak tergantung pada jenis susunan lampu)" sebesar 3,9\%.

Argumentasi-argumentasi yang teridentifikasi miskonsepsi terhadap konsep (7) antara lain: (a) tegangan sumber sama dengan jumlah masing-masing tegangan lampu; (b) semakin jauh dari sumber tegangan makin kecil tegangannya; (c) pada rangkaian paralel, karena $\mathrm{RA}>\mathrm{RB}$ $>\mathrm{RC}$ maka $\mathrm{VA}>\mathrm{VB}>\mathrm{VC}$, . Jadi hambatan mempengaruhi tegangan; dan (d) hambatan di A lebih besar sehingga nyala terang lampu lebih redup dibandingkan $\mathrm{B}$ dan $\mathrm{C}$. Argumentasi-argumentasi yang diberikan siswa dan berlabel miskonsepsi ini dikarenakan siswa tidak memahami karakteristik rangkaian paralel

secara utuh. Dengan kata lain siswa tidak mampu membedakan karakteristik penentu yaitu tegangan dari sejumlah karakteristik umum yang dimiliki oleh konsep pada rangkaian paralel. Konsep yang tidak lengkap tersebut dipercayai siswa sebagai konsep yang sudah lengkap dan benar, sehingga akan mengantarkan siswa pada kegagalan dalam mempelajari fisika atau miskonsepsi (Ibrahim, 2012: 14).

Argumentasi siswa berlabel miskonsepsi terhadap konsep (8) antara lain: (a) tegangan mengalir dalam rangkaian sehingga lampu yang ditemui pertama kali akan menyala terang karena tegangan belum mendapatkan hambatan; (b) lampu yang dilewati arus listrik pertama kali akan menyala lebih terang; (c) lampu yang dekat dengan baterai akan menyala paling terang karena mendapatkan energi pertama kali; (d) sakelar ditutup, tidak ada arus yang mengalir; dan (e) lampu yang 
dirangkai parallel akan meyala lebih terang daripada lampu yang dirangkai seri pada rangkaian campuran. Siswa memberikan argumentasi-argumentasi di atas berdasarkan pengalaman yang diperoleh dari lingkungan, salah satunya karena pengaruh bahasa keseharian, misalkan buka sakelar adalah untuk mematikan lampu dan tutup sakelar untuk menyalakan lampu. Informasi yang salah atau penjelasan yang berbeda dari latar belakang lingkungan siswa dapat menyebabkan terjadi miskonsepsi pada siswa (Ibrahim, 2012: 16).

Miskonsepsi argumentasi (a) dialami siswa dimungkinkan karena siswa menerapkan pola pikir seperti rangkaian pada senter, di mana posisi sakelar terletak antara kutub positif baterei dan lampu. Penelitian Kucukozer et al. (2007) menemukan miskonsepsi yang sama seperti (d) pada konsep kondisi nyala lampu pada rangkaian campuran jika sakelar tertutup sebesar 32,9\%, dan miskonsepsi (a) yang menyatakan bahwa "arus listrik dikonsumsi oleh rangkaian" sebesar 13\%. Miskonsepsi argumentasi (a), (b), dan (c) yang dialami siswa, menjelaskan bahwa siswa mengalami kesulitan membedakan arus listrik, tegangan, dan energi listrik, sehingga siswa menggunakannya bergantian. Siswa tidak memahami bahwa yang dikonsumsi lampu adalah bukan arus listrik melainkan energi dengan cara berubah ke bentuk lain.

Argumentasi yang berlabel miskonsepsi terhadap konsep (9) antara lain: (a) jika sakelar dibuka, maka listrik tidak akan tersambung; (b) pada rangkaian tertutup, jika sakelar terbuka maka semua lampu mati, karena tidak ada arus yang mengalir; dan (c) lampu yang dialiri arus pertama kali akan menyala paling terang. Argumentasi ini dikarenakan penguasaan konsep siswa yang tidak lengkap dan salah dalam menggeneralisasi sehingga memicu terjadinya miskonsepsi (Ibrahim, 2012:14).

Miskonsepsi (a) terjadi karena siswa terpengaruh bahasa sehari-hari bahwa jika sakelar di buka maka lampu akan mati, tidak peduli dimana posisi lampu. Miskonsepsi ini juga ditemukan pada penelitian Kucukozer et al. (2007) dengan persentase 25,0\%. Pada miskonsepsi (c) ditemukan dengan persentase sebesar 8,7\% dengan "argumentasi rangkaian mengkonsumsi arus listrik". Sedangkan miskonsepsi (b) posisi sakelar yang terbuka tidak berpengaruh terhadap nyala lampu merupakan miskonsepsi yang belum ditemukan pada penelitianpenelitian sebelumnya.

Argumentasi-argumentasi siswa yang berlabel miskonsepsi terhadap konsep (10) antara lain: (a) amperemeter seharusnya dipasang pada rangkaian seri, sedangkan voltmeter seharusnya dipasang pada rangkaian paralel; (b) pemasangan amperemeter dan voltmeter dalam rangkaian tidak berpengaruh terhadap nyala lampu; (c) rangkaian I, II, dan IV adalah rangkaian seri dengan satu hambatan dan menyala lebih terang, sedangkan III, dan IV adalah rangkaian paralel dengan satu hambatan sehingga nyala lampu lebih redup; dan (d) amperemeter dan voltmeter hanya untuk mengukur arus listrik, jadi tidak berpengaruh terhadap besarnya tegangan. Miskonsepsimiskonsepsi tersebut terjadi pada siswa disebabkan karena siswa tidak paham dengan fungsi amperemeter dan voltmeter bagi komponen listrik, tidak memahami syarat pemasangan kedua alat ukur tersebut pada rangkaian, serta tidak memiliki pengalaman merangkaikan amperemeter dan voltmeter pada rangkaian. Jumlah atribut yang relevan dan tidak relevan, yang digunakan ketika mengajarkan konsep akan berpengaruh terhadap tingkat kesulitan dalam memperoleh/ memahami suatu konsep (Ibrahim, 2012:15). Penelitian Kucukozer et al. (2007) untuk konsep yang sama menemukan miskonsepsi (c) di mana siswa memberikan argumentasi bahwa "lampu dalam rangkaian seri selalu menyala lebih terang”.

Hasil analisis terhadap hubungan peningkatan penguasaan konsep dan reduksi miskonsepsi diperoleh bahwa variabel penguasaan konsep siswa memberikan kontribusi $39,2 \%$ terhadap reduksi miskonsepsi siswa, sedangkan $60,8 \%$ ditentukan oleh variabel lainnya yang tidak diikutkan dalam penelitian ini. Hubungan dinyatakan dalam persamaan regresi $\mathrm{Y}=0,876-0,095 \mathrm{X}$. Persentase miskonsepsi awal siswa terbesar adalah sebesar 0,876. Diperlukan perubahan penguasaan konsep siswa sebesar 9,2 untuk mereduksi miskonsepsi siswa dengan sempurna.

\section{SIMPULAN}

Berdasarkan hasil analisis data dan pembahasan dapat diambil kesimpulan yaitu terdapat pengaruh signifikan model pembelajaran kooperatif dengan strategi konflik kognitif terhadap penguasaan konsep dan reduksi miskonsepsi siswa pada pokok bahasan rangkaian listrik sederhana.

Berdasarkan hasil temuan penelitian yang dilakukan, peneliti memberikan saran sebagai berikut: miskonsepsi siswa terhadap konsep beda potensial di antara dua titik bersifat resistan. Hal ini menunjukkan bahwa strategi konflik kognitif tidak lebih efektif dalam hal mereduksi miskonsepsi siswa terhadap konsep beda potensial di antara dua titik. Perlu dilakukan penelitian lebih lanjut dengan menggunakan strategi pembelajaran lain sebagai upaya mereduksi miskonsepsi beda potensial di antara dua titik.

\section{DAFTAR PUSTAKA}

Baser, M. 2006. "Forstering Conceptual Change By Cognitive Conflict Based Instruction on Students' 
Understanding of Head and Temperature Concepts".

Eurasia Journal of Mathematics, Science and Technology Education. Vol. 2, No. 2 .

Dilber, R. and Duzgun, B. 2007. "An Investigation of Effectiveness of Conceptual Change Text-Oriented Instruction on Students' Understanding of Brigthness Concepts". Journal of Science Education-ProQuest Education Journals. Vol. 8, No.1, 2007. Pp. 46-52.

Dilber, R. and Duzgun, B. 2008. "Effectiveness of Analogy on Student's Success and Elimination of Misconcepcions". Journal of Science Education. Vol. 2, No. 3, July 2008. Pp. 174-183.

Faizin, M. N. 2009. "Interactive Flash Modelliling (IMF) Usage to Reduce Mosconception in Dynamic Electrical and ti Improve The Students's Learning Attitude". Proceeding of The Third Internasional Seminar on Science Education. Science Education Program, Graduate School. Indonesia University of Education (IUE). ISBN: 978-602-8171-14-1. Pp. 516525

Hake, R. R. 1999. "Interactive-engagement Methods in Introductory Mechanics Courses" Journal of Physics Education Research.

Hasan, S, Bagayoko, D, and Kelly, E. L. 1999. "Misconception and The Certainty of Response Index". Journal of Physics Education. Vol. 34, No.5.

Ibrahim, M. 2012. Seri Pembelajaran Inovatif Konsep, Miskonsepsi, dan Cara Pembelajarannya. Surabaya: Unesa University Press.

Indrawati. 2009. "The Misconception of Physics Teacher Prospective Students about Law of Reflection". Proceeding of The Third Internasional Seminar on Science Education. Science Education Program, Graduate School. Indonesia University of Education (IUE). ISBN: 978-979-98546-4-2. Pp. 244-250.

Kucukozer, H. and Kocakulah, S. 2007. "Secondary School Students' Misconception about Simple Electric Circuits". Jurnal of Turkish Science Education. Vol. 4, No. 1, May 2007. Pp. 101-116.

Mansyur, J. and Kaharu, S. N. 2002. "Differentiating Misconception and Lack of Knowledge: Case of Bulb Poles". Preceeding of The Second Internasional Seminar on Science Education. Science Education Program, Graduate School. Indonesia University of Education (IUE). ISBN: 978-979-98546-4-2. Pp. 319323.

Mardana, I. 2004. "Pengembangan Model Simulasi Komputer Berorientasi Konstruktivisme Sebagai Inovasi Teknologi Pembelajaran Pengubah Miskonsepsi untuk Meningkatkan Hasil Belajar Fisika Siswa SMU". Jurnal Pendidikan dan Pengajaran IKIP Negeri Singaraja. No. 4 TH. XXXVII, Oktober 2004
Pp. 57-71.

Mosik, M. P. 2010. "Usaha Mengurangi Terjadinya Miskonsepsi Fisika Melalui Permbelajaran dengan Pendekatan Konflik Kognitif". Jurnal Pendidikan Fisika Indonesia. Juli 2010. Pp. 98-103.

Sadia, I W., 2004. "Efektivitas model Konflik Kognitif dan Model Siklus Belajar untuk Memperbaiki Miskonsepsi Siswa dalam Pembelajaran Fisika”. Jurnal Pendidikan dan Pengajaran IKIP Negeri Singaraja. No. 3 TH. XXXVII. Juli 2004. Pp. 40-58.

Saehana, S. dan Haeruddin . 2009. "Development of Computer Simulation in Cooperative Learning Model to Minimize The Misconception Physics in High School Students in Palu". Tadulako University. Proceeding of The Third Internasional Seminar on Science Education. Science Education Program, Graduate School. Indonesia University of Education (IUE). Pp. 516-525.

Said, M. U. 2012. "Pengembangan Perangkat Pembelajaran Berbasis Lab Mini untuk Meremidiasi Miskonsepsi Siswa SMA”. Tesis: PPs. Unesa.

Samsuri. 2010. Pengembangan Perangkat Pembelajaran Berbasis Media Simulasi PhET dan KIT Sederhana Pada Pembelajaran Fisika SMA Pokok Bahasan Listrik Sederhana. Tesis: PPs. Unesa.

Simarmata, U. 2008. "Penerapan Model Konstruktivis dalam Pembelajaran Fisika di SMU dalam Upaya Menanggulangi Miskonsepsi Siswa”. Jurnal Pendidikan Matematika dan Sains. ISSN: 1907-7157. Vol. 2, No. 3. 2008. Pp. 77-82.

Sirait, J. 2009. "Cognitive Conflict Approach to Increase Critical Thinking of The Students in Physics".

Proceeding of The Third Internasional Seminar on Science Education. Science Education Program, Graduate School. Indonesia University of Education (IUE). ISBN: 978-602-8171-14-1. Pp. 429-438.

Smith, D. P. and Kampen, P. V. 2011. "Taching Electric Circuits with Multiple Batteries: A qualitative Approach". Journal of American Physical Society.

Suparno, P. 2013. Miskonsepsi \& Perubahan Konsep dalam Pendidikan Fisika. Jakarta: PT. Grasindo.

Sutrisno, W. 2009. "Penumbuhan Sikap-sikap Positif melalui Pembelajaran Fisika". Jurnal Pengajaran Fisika Sekolah Menengah. Vol. 1 No. 1. Februari 2009. Pp. 14-17.

Triyanta. 2009. "Medan Magnetik sebagai Efek Relativistik dari Gaya Coulomb dan Miskonsepsi yang Terkait dalam Pembelajaran Kemagnetan”. Jurnal Pengajaran Fisika Sekolah Menengah. Vol.1, No.2, Mei 2009. Pp. 40-47.

Trumper, R. 1990. "Being Conctructive: An Alternatif 
Approach to The Teaching of Energy Concept". International Journal of Science Education. Vol. 12, No. 4. 1990. Pp. 343-354.

Tsai, C.-H. Chen, H-Y., Chou, C-Y., \& Lain, K-D. 2007. "Current as the Key Concept of Taiwanese Students' Understanding of Electric Circuits". International Journal of Science Education. Vol. 29, No.4, March 2007. Pp. 483-496. 